\title{
Apoplasm hydrostatic pressure on growth of cylindrical cells
}

\author{
José Dalton Cruz Pessoa ${ }^{1 *}$ and Adonai Gimenes Calbo ${ }^{2}$
}

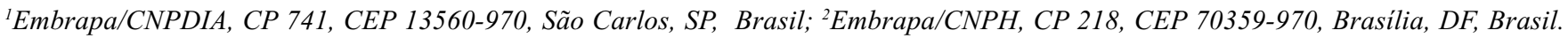 \\ *Corresponding author: dalton@cnpdia.embrapa.br
}

Received: 29/09/2003, Accepted: 09/02/2004

According to the model frequently used as reference, plant cell growth occurs only when turgor surpasses a threshold. This model was proposed considering a cylindrical cell of constant wall thickness immerged in a water solution, with viscoelastic behaviour, hydraulic conductivity, variable extensibility, and unidirectional elongation. The author, Lockhart (1965), did not consider the effects of apoplasm hydrostatic potential, a subject treated later by Calbo and Pessoa (1994) who argued that this component of cell potential would interfere with cell growth rate. To evaluate this effect, where possible the same deductive procedures as those employed by Lockhart were used here, which resulted in a set of equivalent equations for cell growth, turgor and water potential, developed with respect to physico-chemical variables. Relationships were derived from the conductivity equation, the definition of extensibility, Hook's law, and considering that the tension on cell wall transversal section is proportional to turgor and apoplasm hydrostatic potential. The numeric solutions for the equations showed that suction increased extension rate at the beginning of cell growth. Some experiments on plant growth and structural models of cell walls are discussed to point out the role of suction on wall tensioning and cell hydration during cell elongation.

Keywords: apoplasm, cell wall, growth, Lockhart, model, plant.

Pressão hidrostática do apoplasma no crescimento de células cilíndricas: De acordo com o modelo freqüentemente referenciado o crescimento celular vegetal ocorre somente quando a turgescência ultrapassa um valor limite. Esse modelo foi proposto para uma célula cilíndrica imersa em solução aquosa e com paredes de espessura constante, de comportamento viscoelástico, com condutividade hidráulica, extensibilidade variável e alongamento unidirecional. Seu autor, Lockhart (1965), não considerou os efeitos do potencial hidrostático do apoplasma, um assunto tratado posteriormente por Calbo e Pessoa (1994) que argumentaram que esse componente do potencial poderia interferir na taxa de crescimento celular. Para avaliar tal efeito, na medida do possível, os mesmos procedimentos dedutivos empregados por Lockhart foram usados aqui, resultando em um conjunto equivalente de equações para o crescimento celular, turgescência e potencial da água, obtidos usando variáveis físico-químicas. As relações foram derivadas a partir das equações da condutividade, da definição da extensibilidade, da lei de Hook e considerando que a tensão na seção transversal é proporcional à turgescência e ao potencial hidrostático do apoplasma. As soluções numéricas das equações mostraram que a sucção aumenta a taxa de alongamento no começo do crescimento. Alguns experimentos sobre o crescimento vegetal e modelos estruturais da parede celular são discutidos para indicar o papel da sucção no tensionamento da parede e na hidratação durante o alongamento celular.

Palavras-chave: apoplasma, crescimento, Lockhart, modelo, parede celular, planta.

\footnotetext{
Abbreviations: $r$ - cell radius; L - cylindrical cell length; s - cylindrical cell length free of external forces; A - cell wall area; $A_{S}$ - protoplasm transversal area; $\mathrm{A}_{\mathrm{a}}$ - apoplasm transversal area; $\mathrm{V}$ - cell volume; $\mathrm{t}$ - time; $\mathrm{F}$ - applied force through cell main axis; $\mathrm{E}$ - elastic module; $\mathrm{K}$ cell wall hydraulic conductivity; $\mathrm{P}_{\mathrm{S}}$ - turgor; $\mathrm{P}_{\mathrm{e}}$ - threshold turgor from which occurs plastic growth; $\mathrm{P}_{\mathrm{a}}$ - apoplasm hydrostatic pressure; $\sigma$ $=\mathrm{P}_{\mathrm{s}} \cdot \mathrm{A}_{\mathrm{S}} / \mathrm{A}_{\mathrm{a}} \cdot \operatorname{Pr}=\mathrm{P}_{\mathrm{a}}+\sigma$. Stress under cell wall; $\mathrm{Y}$ - total cell wall stress from which cell grows; $\Theta$ - proportionality constant between net stress on cell wall and its elongation rate; $\Pi(\mathrm{MPa})$ - the concentration of osmotically active solutes within the cell, taken to be equal to the hydrostatic pressure which must be exerted on an osmometer containing the same solution to maintain flux equilibrium with pure water at atmospheric pressure; Пe $(\mathrm{MPa})$ - The osmotic pressure of the solution in which a cell is immersed, equal to zero for pure water at atmospheric pressure; $\Delta \Pi=\Pi$-Пe. Osmotic pressure (positive values); $\Psi_{\mathrm{ws}} \equiv \mathrm{Ps}-\Delta \Pi \mathrm{s}-$ Protoplasm water potential; $\Psi_{\mathrm{wa}} \equiv \mathrm{Pa}-\Delta \Pi \mathrm{a}-$ Apoplasm water potential; $\Delta \Psi_{\mathrm{SS}}-$ Protoplasm osmotic potential. Modern version of $-\Delta \Pi$. Can assume negative values; $\alpha$ - transversal cell wall area; $\delta$ - cell wall thickness; $\Phi$ - extensibility; $\varphi=\Phi / 2 \delta$; $\varepsilon$ - estimated error from approximations.
} 


\section{INTRODUCTION}

In 1965, Lockhart published "An analysis of irreversible plant cell elongation" in which he modeled the growth of an ideal cell, cylindrically shaped, of constant radius and wall thickness, immerged in a constant temperature water-bath under isothermal conditions and free of external forces. The best known hypothesis of this work is that a cell reaches its plastic growth phase when turgor $(\mathrm{P})$ is larger then a given threshold value $\left(\mathrm{P}_{\mathrm{e}}\right)$.

He derived equations describing cell elongation considering that: relative volume increase of a cylindrical cell with constant radius is equivalent to elongation along the axis; if ' $\mathrm{s}$ ' is the cell length under 0 -force and ' $\mathrm{L}$ ' is the observed length, 's' and ' $\mathrm{L}$ ' relate to each other according to Hook's law; water flux through the cell wall could be quantified by the conductivity equation and; cell wall behaves like a vicoelastic element. He solved the growth equation for four cases ( $\Delta \Pi$ - osmotic pressure, $\phi$ - extensibility): $1-\Delta \Pi$ and $\phi$ are independent of time; $2-\Delta \Pi$ is a function of cell volume; 3- $\phi$ is a function of time and; $4-\Delta \Pi$ is a function of cell length and $\phi$ is a function of time.

Lockhart (1965) concluded that the experimental observed growth behaviour could be simulated when (i) $\Delta \Pi$ is constant and (ii) when osmotic solutes are diluted out with elongation. In both cases $\phi$ is a linear function decreasing with time. When osmotic pressure is constant the dynamics of cell elongation appear to be a sigmoid, ceasing growth after approximately 50 hours with the values used. When osmotic solutes are diluted out the growth curve is linear at the beginning until ceasing assymptotically after $20 \mathrm{~h}$.

Calbo \& Pessoa (1994) considered that the tension responsible for cell wall elongation depends not only on turgor $\left(\mathrm{P}_{\mathrm{S}}\right)$, but also on apoplasm hydrostatic pressure $\left(\mathrm{P}_{\mathrm{a}}\right)$. The tension $\sigma(\mathrm{MPa})$ induced in the cell wall by turgor depends on the relation between transversal areas of protoplasm $\left(\mathrm{A}_{\mathrm{S}}\right)$ and apoplasm $\left(\mathrm{A}_{\mathrm{a}}\right), \sigma \cdot \mathrm{A}_{\mathrm{a}}=\mathrm{P}_{\mathrm{s}} \cdot \mathrm{A}_{\mathrm{S}}$, so that cell wall total tension (pr) would result from the sum: $\mathrm{pr}=\mathrm{P}_{\mathrm{a}}+\sigma$.

In this paper we evaluate new relations for cell growth considering the effect of apoplasm hydrostatic pressure on wall tensioning, that becomes more prominent when growth starts under water stress.

\section{MATERIAL AND METHODS}

In this paper, the Lockhart (1965) deductions are reevaluated considering the hypothesis of Calbo \& Pessoa (1994) which assumes that cell elongation depends not only on turgor but also on apoplasm hydrostatic potential.

\section{Assumptions}

1- No external mechanical forces (tension or compression) act on the cell wall.

2- Temperature is constant.

3- The cell grows only along the main axis.

Following Lockhart (1965), we will consider a cylindrical cell having radius ' $r$ ', initial length' 's', and viscoelastic wall of thickness' ' $\delta$ ' immersed in a water solution. To facilitate the observation of the effect of apoplastic hydrostatic pressure, the original terms from Lockhart (1965) for osmotic potential will be maintained where necessary:

$\Pi$ (MPa) -'"the concentration of osmotically active solutes within the cell, taken to be equal to the hydrostatic pressure which must be exerted on an osmometer containing the same solution to maintain flux equilibrium with pure water at atmospheric pressure".

Пе $(\mathrm{MPa})$ - "The osmotic pressure of the solution in which a cell is immersed, equal to 0 for pure water at atmospheric pressure".

$\Delta \Pi=\Pi$ - Пе.

The equivalent of $\Delta \Pi$ in present-day terms is $\Delta \Psi_{\mathrm{SS}}$, representing the protoplasm osmotic potential that can reach negative values. Using this nomenclature, the water protoplasmic potential is written as $\Psi_{\mathrm{Ws}}=\mathrm{P}_{\mathrm{S}}-\Delta \Pi_{\mathrm{S}}$.

Elastic Elongation: A (cylindrical) cell with a primary viscoelastic wall immersed in a solution tends to equilibrate its hydrostatic potential with osmotic potential of the medium by regulating ionic concentration. A force (F) applied to the wall transversal section $(\alpha)$, stretches it from length ' $s$ ' to length 'L' according to Hook's law, while constrained by wall extensibility $(\Phi)$.

If the pressure $(F / \alpha)$ responsible for wall elongation or shortening depends on turgor $\left(\mathrm{P}_{\mathrm{S}}\right)$ and suction $\left(\mathrm{P}_{\mathrm{a}}\right)$, it can be written according to Calbo \& Pessoa (1994) as:

$$
\frac{F}{\alpha}=P_{a}+\frac{A_{S}}{A_{a}} P_{S}
$$

where $\mathrm{A}_{\mathrm{s}}$ and $\mathrm{A}_{\mathrm{a}}$ are the areas of protoplasm and apoplasm transversal sections.

Substituting F/ $\alpha$ (Eq. 1) in the extensibility definition and specifying for a cylindrical cell,

$$
P_{s}=\left[\frac{1}{\Phi} \frac{d s}{s d t}-P_{a}\right] \frac{2 \delta}{r}
$$


Growth rate depends on the pressure gradient and the wall membrane hydraulic conductivity $(\mathrm{K})$ :

$$
\frac{d L}{L d t}=\frac{2 K}{r}\left[\Delta \Pi-\left(P_{s}+P_{a}\right)\right]
$$

Substituting for $\mathrm{P}_{\mathrm{S}}$ (Eq. 2) in the conductivity equation above, we obtain a new formula for elastic extension as a function of cell physical-hydric characteristics $(\phi=\Phi /(2 \delta))$

$$
\frac{d L}{L d t}=\frac{2 K r \phi}{2 K+r^{2} \phi}\left(\Delta \Pi+\left(\frac{2 \delta}{r}-1\right) P_{a}\right)
$$

Equations for $P_{S} e \Psi_{w}$ : To obtain a relation for $\mathrm{P}_{\mathrm{S}}$ as a function of physical-hydric parameters, it is sufficient to substitute the conductivity equation (Eq. 3 ) in relationship (2), (s $\approx$ L)

$$
P_{s}=\frac{4 \delta K}{\phi \cdot r^{2}+4 \delta K} \Delta \Pi-\left[\frac{4 \delta K}{\phi \cdot r^{2}+4 \delta K}\left(1-\frac{2 \delta}{r}\right)+\frac{2 \delta}{r}\right] P_{a}
$$

from which we obtain the expression for protoplasm water potential $\left(\Psi_{\mathrm{W}}=\mathrm{P}_{\mathrm{s}}-\Delta \Pi\right)$ :

$$
\Psi_{w}=-\left(\frac{\phi \cdot r^{2}}{\phi \cdot r^{2}+4 \delta K}\right) \Delta \Pi-\left[\frac{4 \delta K}{\phi \cdot r^{2}+4 \delta K}\left(1-\frac{2 \delta}{r}\right)+\frac{2 \delta}{r}\right] P_{a}
$$

Plastic Elongation: According to the Lockhart model, irreversible cell size variation occurs when the force on a wall transversal section surpasses a limit value that depends on turgor. According to Calbo and Pessoa (1994) this force also depends on $\mathrm{P}_{\mathrm{a}}$, and consequently on $\frac{d s}{s d t}=\Theta(p r-Y)$, where ' $\mathrm{Y}$ ' is the new limit value and $\Theta$ the proportionality constant. Substituting $d s / s d t$ in the $\mathrm{P}_{\mathrm{S}}$ expression (Eq. 2) and then in the hydraulic conductivity equation (3), we arrive at the expression:

$$
\frac{d L}{L d t}=\frac{2 K \Theta}{A_{s} r \Theta+2 K A_{a}}\left[\Delta \Pi A_{s}+\left(A_{a}-A_{s}\right) P_{a}-A_{a} Y\right]
$$

Substituting $A_{\mathrm{S}}=\pi \mathrm{r}^{2}, \mathrm{~A}_{\mathrm{a}}=2 \pi \mathrm{r} \delta$ and $\varphi=\Theta /(2 \delta)$ :

$$
\frac{d L}{L d t}=\frac{2 K r \varphi}{2 K+r^{2} \varphi}\left[\Delta \Pi+\left(\frac{2 \delta}{r}-1\right) P_{a}-\frac{2 \delta}{r} Y\right]
$$

establishes the relation for plastic growth as a function of hydric potentials and variables caracteristic of the cell.

Validity of previous deductions: In order for the presented deductions to be valid, the approximation $\mathrm{s} \cong \mathrm{L}$ must be true. Deriving from Hook's law and substituting the tension term F/ $\alpha$ (Eq. 1), we get

$$
\frac{d L}{L d t}=\frac{s}{L E}\left[\frac{d P_{a}}{d t}+\frac{r}{2 \delta} \frac{d P_{s}}{d t}\right]+\frac{d s}{s d t}
$$

that shows the condition for validity of the approximation to be:

$$
\frac{d P_{a}}{d t}+\frac{r}{2 \delta} \frac{d P_{S}}{d t} \approx 0
$$

\section{RESULTS AND DISCUSSION}

In Material and Methods we assumed that no external mechanical force acts on the cylindrical submerged cell. This is a simplifying assumption to avoid a water column pressure term if the cell is deep submerged, and the adhesion force between water solution molecules and the cell wall. If the cell is part of a plant tissue, compression from closest neighbours is even stronger and the assumption has less validity.

Assumption 2 was also adopted by Lockhart (1965) and avoids rate changes in biochemical reactions that would have an influence in cell elongation, independent of wall tensioning.

Cell growth occurs by expansion (increase in size in two or three dimensions) or by elongation (expansion constrained exclusively in one dimension). In axial organs such as roots and stems the diameter of the cells usually increases by less than $5 \%$, which justifies the simplification of assumption 3 . When a cell is mature for growth, cross-linking polymers, like xyloglucans, loosen their connections with cellulose and hemicellulose fibers. If the cell wall is under a high enough tension the cell grows until cross-link stiffening and extensin deposition occurs. The biochemical process for cross-linking relaxation is still elusive but much data demonstrate the concurrence of a rapid acidification phase (Kutchera, 2000).

Cell wall and then apoplastic volumes are generally in the $3-5 \%$ range of total cell volume and exceptionally can reach $40 \%$, which should be important in water supply to the protoplasm. This proportion depends on apoplasmic volume and the pectic matrix, which determine wall capacitance and, therefore, the amount of water stored for a certain potential. Pasioura (1994) suggested that wall hydration determines both variable expansibility behavior and the turgor threshold from which plastic growth starts. If relative water content is low the wall contracts, impeding the enzymatic breakdown of xyloglucan chains and stopping lengthening. Otherwise the turgor can force the connections between the cellulose fibers and xyloglucans, until the enzymes break some xyloglucan chains and the cell expands in a proportion determined by the enzymatic action. Edelmann (1995) measured coleoptile extensibility of rice incubated in solutions with different potentials and confirmed the dependence of extensibility on environmental potential. 
To evaluate the $\mathrm{P}_{\mathrm{a}}$ effect on elastic elongation, we will assume that in all simulations the apoplasm hydrostatic potential behaves as follows:

$$
P_{a}=\frac{-1}{a \cdot t+p_{a}^{o}}
$$

Using the values $\mathrm{a}=1 \mathrm{MPa} \cdot \mathrm{s}^{-1}$ and $\mathrm{p}_{\mathrm{a}}{ }^{\mathrm{o}}=2 \mathrm{MPa}, \mathrm{P}_{\mathrm{a}}$ reaches $1 \%$ of its initial value in approximately 3.5 minutes (figure 1). We will also assume the same values as those used by Lockhart: $\mathrm{K}=5 \times 10^{-9} \mathrm{~m} \cdot \mathrm{s}^{-1} \mathrm{MPa}^{-1}$ (hydraulic conductivity), $\mathrm{r}=10^{-5} \mathrm{~m}$ (cell radius), $\delta=10^{-6} \mathrm{~m}$ (cell wall thickness), $\Delta \Pi=$ $0.1 \mathrm{MPa}$ (osmotic pressure), and $\phi=6944 \mathrm{MPa}^{-1} \mathrm{~s}^{-1} \mathrm{~m}^{-1}$ (extensibility). When $\phi$ is time dependent, it will decrease linearly: $\phi=\phi_{\mathrm{O}} \mathrm{c}^{-\mathrm{t}}\left(\phi_{\mathrm{O}}=50 \mathrm{MPa}^{-1} \mathrm{~s}^{-1} \mathrm{~m}^{-1}, \mathrm{c}=0.2 \mathrm{MPa}^{-1} \mathrm{~s}^{-2} \mathrm{~m}^{-1}\right)$.

Case I: $\Delta \Pi$ and $\phi$ constants: In this case, the solution to Lockhart's growth equation is an exponential function, while the solution for equation 4 adds a second term that divides it. Expressing the elastic elongation $\left(\mathrm{L} / \mathrm{L}_{\mathrm{O}}\right)$ in logarithmic form, we obtain:

$\operatorname{Ln}\left(\frac{L}{L_{o}}\right)=\frac{2 K r \phi}{2 K+\phi \cdot r^{2}}\left[\Delta \Pi t-\left(\frac{2 \delta}{r}-1\right) \frac{1}{a} \operatorname{Ln}\left(\frac{a \cdot t}{P_{a}^{o}}+1\right)\right]$

This is an unlikely situation where elongation does not affect, nor is effected, by physiological processes, such as osmotic adjustments and cell wall structural changes.

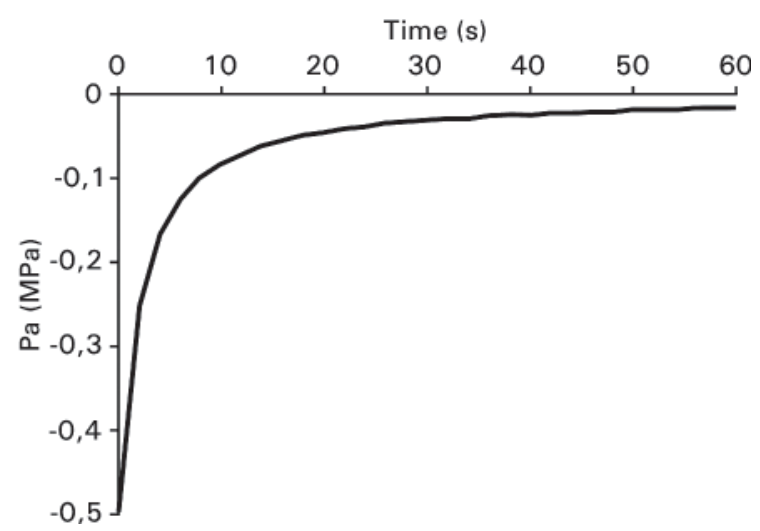

Figure 1. Apoplasm hydrostatic potential versus time, according to equation 11.

The curves obtained from Equation 12 and the curve obtained by Lockhart, both computed using the parameter values previously mentioned, are shown in figure 2 . It shows that $\mathrm{P}_{\mathrm{a}}$ increases significantly the elongation rate, decreasing its effect as $\mathrm{P}_{\mathrm{a}}$ approximates to zero.

Case II: $\Delta \Pi$ is constant and $\phi$ is a linear function of time: In this case expansibility reduces to zero after $250 \mathrm{sec}$, much later than $\mathrm{P}_{\mathrm{a}}$, that in $20 \mathrm{sec}$ reduces to $10 \%$ of its initial value. Figure 3 shows the elongation rate with and without $\mathrm{P}_{\mathrm{a}}$. Although the expansibility reduces only $8 \%$ in $20 \mathrm{sec}$, it is enough to diminish significantly the high elongation rate observed in case I, which reflects the importance of cell wall structure changes during cell growth.

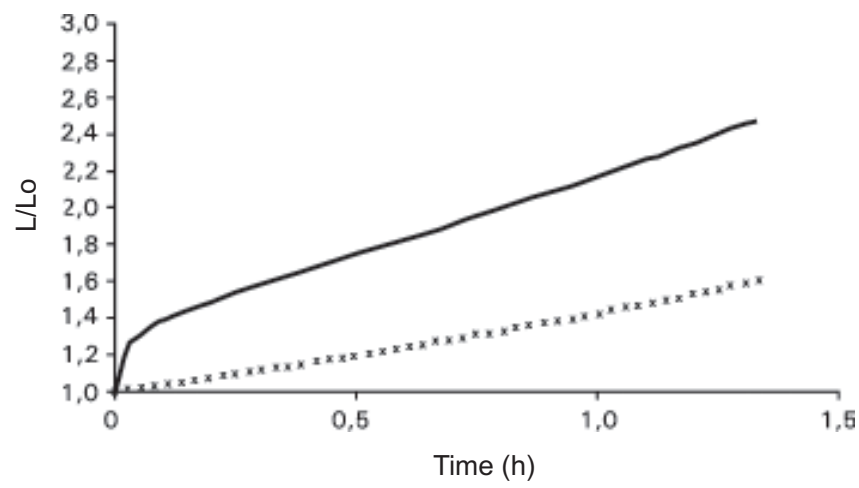

Figure 2. $\mathrm{L}_{\mathrm{o}}$ - initial length of the cell, $\mathrm{L}$ - actual length of the cell. L/Lo- relative elastic extention of the cell for $\Delta \Pi(=0.1 \mathrm{MPa})$ and $\phi\left(=6944 \mathrm{MPa}^{-1} \cdot \mathrm{s}^{-1} \cdot \mathrm{m}^{-1}\right)$ constants (case I); x- acording to Lockhart ; Continous line- effect of $\mathrm{P}_{\mathrm{a}}$ on elastic extension
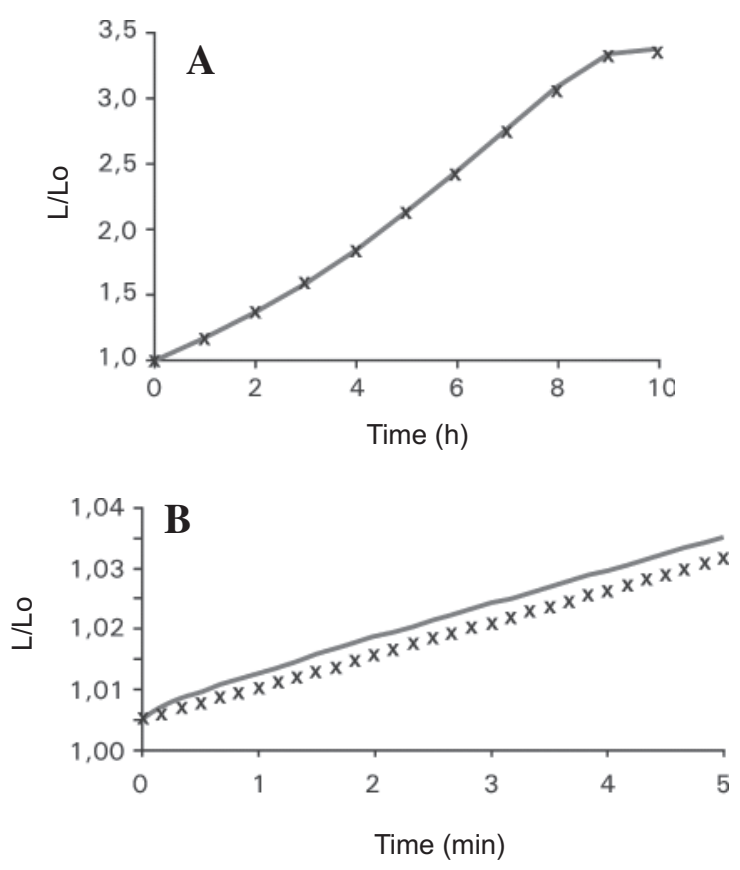

Figure 3: Relative elastic extention $\left(\mathrm{L} / \mathrm{L}_{\mathrm{o}}\right)$ of a cylindrical cell; a) ' $x$ ' line was obtained by Lockhart (1965), that did not considered $\mathrm{P}_{\mathrm{a}}$ effect. On continuous line $\mathrm{P}_{\mathrm{a}}$ effect was computed for Case II: $\Delta \Pi=0.1 \mathrm{MPa}$ and $\phi=\phi_{\mathrm{O}^{-}} \mathrm{c}^{* \mathrm{t}}$ $\left(\phi_{\mathrm{o}}=50 \mathrm{MPa}^{-1} \cdot \mathrm{s}^{-1} \cdot \mathrm{m}^{-1}, \mathrm{c}=0.2 \mathrm{MPa}^{-1} \cdot \mathrm{s}^{-2} \cdot \mathrm{m}^{-1}\right)$. The difference between simulations are better observed on Fig 3B; b) detail of the extension curve with and without $\mathrm{P}_{\mathrm{a}}$ contribution up to 5 minutes (Eq 11). 
Case III: $\Delta \Pi$ is a function of volume and $\phi$ of time: In this case, the elongation was computed using $\Delta \Pi \cdot \mathrm{L}(\mathrm{t})=\Delta \Pi_{\mathrm{o}} \cdot \mathrm{L}_{\mathrm{o}}$, where the subscript 'o' indicate that $\Delta \Pi \cdot$ and $\mathrm{L}$ are constants:

$$
\frac{d L}{d t}=\frac{2 K r(\phi-c t)}{2 K+(\phi-c t) r^{2}}\left[\Delta \Pi_{o} L_{o}-\left(\frac{2 \delta}{r}-1\right) \frac{L(t)}{a t+p_{a}^{o}}\right]
$$

Compared with Lockhart's equation in Table 1 the right term inside the brackets increases the initial elongation rate. The graphs of both equations are shown in figure 4. From figures 4 and $3 \mathrm{~B}$ we can also observe that a decreasing $\Delta \Pi$ did not contribute significantly to initial elongation rate, which indicates again the importance of $\phi$ and consequently the cell wall structural dynamics.

In a paper on water flux in apoplasm, Canny (1995b) explored many experimental results and suggested four classifications for apoplasm, according to its functions and properties. 1- Xylem-lumen apoplast are ducts capable of supporting water columns stressed to 60 bar or more. Through them, water flows according to the Hagen-Poiseuille flux where fluid velocity is proportional to the square of duct diameter. 2- Water free-space corresponds to wet intercellular and cell wall spaces. Fluid moves through them like a film, as in a porous medium or, in the absence of a pressure gradient, by diffusion. 3- Part of it is specifically denominated Donnan free-space, corresponding to the electronegative part of the cell wall which modifies the transport rules for charged molecules. 4- Finally, the Intercellular spaces are small and filled with gas in unstable equilibrium and surrounded by a liquid medium.
Although water storage and transport properties result from the interrelation of all these parts, we will restrict ourselves to the water free-space, and with some restrictions to Donnan free-space, partially occupied by a solid phase that limits the protoplasm and establishes its profile because of a xyloglucan chain that connects two or more cellulose microfibrils. The latter are spread on planes 20 to $40 \mathrm{~nm}$ apart which in onion parenchyma with a $100 \mathrm{~nm}$ cell wall contain three or four layers between the plasma membrane and middle lamelae. In the interfibril space of this net, we find chains of polygalacturonic acids and rhamnogalacturans-I, the main structural components of the second (gel-like) net constituting the cell wall and independent of the first. Its electronegative radicals attract positive ions and water dipoles, and are interconnected by $\mathrm{Ca}^{+2}$ bridges determining the shape of the net, in a concentration that increases with cell differentiation. For dividing cells, the ratio between $\mathrm{Mg}^{+2}$ and $\mathrm{Ca}^{+2}$ is $6: 1$ while in differentiated cells, it is the inverse (Nakajima et al., 1981).

We know little about this gel. However, it is made up of chains of $700 \mathrm{~nm}$ approximately which restrict cellulose/ xyloglucans chain movement and is responsible for wall porosity (maximum diameter 10nm) (Baron-Opel et al., 1989) and hydric properties. During cell elongation, one of the most common polymer modifications is the esterification of carboxylic acids, whereby negative charges used by calcium bridges are eliminated. In carrot cells in solution and maize coleoptiles, elongation is related to esterification and ceases with de-esterification. In tobacco cells in suspension, total

Table 1. Comparative table for formulas considering or not $\mathrm{P}_{\mathrm{a}}$ effect.

$\begin{array}{lll}\text { Equation for } & \text { Not considering } \mathrm{P}_{\mathrm{a}} \quad \text { Considering } \mathrm{P}_{\mathrm{a}}\end{array}$

Turgor

$$
P_{s}=\frac{2 K}{\phi \cdot r^{2}+2 K} \Delta \Pi
$$

Total potential

$$
\Psi_{w}=-\left(\frac{\phi \cdot r^{2}}{\phi \cdot r^{2}+2 K}\right) \Delta \Pi
$$

Elastic elongation

$$
\frac{d L}{L d t}=\frac{2 K r \phi}{2 K+r^{2} \phi} \Delta \Pi
$$

Plastic elongation

$$
\frac{d L}{L d t}=\frac{2 K r \phi(\Delta \Pi-Y)}{2 K+r^{2} \phi}
$$

$$
\begin{gathered}
P_{s}=\frac{2 k}{\phi \cdot r^{2}+2 K} \Delta \Pi-\left[\frac{2 K}{\phi \cdot r^{2}+2 K}\left(1-\frac{2 \delta}{r}\right)+\frac{2 \delta}{r}\right] P_{a} \\
\Psi_{w}=-\left(\frac{\phi \cdot r^{2}}{\phi \cdot r^{2}+2 K}\right) \Delta \Pi-\left[\frac{2 K}{\phi \cdot r^{2}+2 K}\left(1-\frac{2 \delta}{r}\right)+\frac{2 \delta}{r}\right] P_{a} \\
\frac{d L}{L d t}=\frac{2 K r \phi}{2 K+r^{2} \phi}\left(\Delta \Pi+\left(\frac{2 \delta}{r}-1\right) P_{a}\right) ;
\end{gathered}
$$

$$
\frac{d L}{L d t}=\frac{2 K r \varphi}{2 K+r^{2} \varphi}\left[\Delta \Pi+\left(\frac{2 \delta}{r}-1\right) P_{a}-\frac{2 \delta}{r} Y\right]
$$


ester proportion is $50 \%$ in dividing cells, $78 \%$ during elongation, and $68 \%$ in the stationary phase. Methyl esters correspond to $50 \%$ of all those found in the division phase. During elongation this rises to $66 \%$. In the stationary phase this proportion does not diminish, from which we conclude that total ester reduction does not come from methyl ester reduction (McCann and Roberts, 1994).

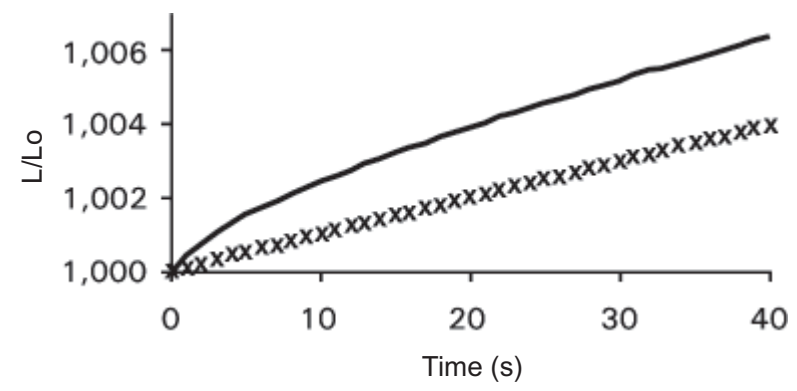

Figure 4. Relative elastic extention $\left(\mathrm{L} / \mathrm{L}_{\mathrm{o}}\right)$ for $\Delta \Pi$ as $\mathrm{A}$ function of volume $\left(\Delta \Pi \cdot \mathrm{L}(\mathrm{t})=\Delta \Pi_{\mathrm{o}} \cdot \mathrm{L}_{\mathrm{o}}\right)$ and $\phi$ as $\mathrm{A}$ function of time $\left(\phi=\phi_{\mathrm{O}} \mathrm{c}^{*} \mathrm{t}, \phi_{\mathrm{O}}=50 \mathrm{~Pa}^{-1} \cdot \mathrm{s}^{-1} \cdot \mathrm{m}^{-1}, \mathrm{c}=0.2 \mathrm{~Pa}^{-1} \cdot \mathrm{s}^{-2} \cdot \mathrm{m}^{-1}\right)$ (Case III). Continous line: considering that $\mathrm{P}_{\mathrm{a}}$ behaves as in figure 1. Line ' $x$ ': when $P_{a}$ is not considered.

Artificial gels present properties that, if confirmed in the cell wall, would help to explain biochemical conditions of thermodynamic potential $\mathrm{P}_{\mathrm{a}}$ under a biochemical approach. These gels have a remarkable capacity for volume reduction induced by small temperature changes, salt-types concentration, $\mathrm{pH}$, and electrical fields. In ionic gels, the positively charged salts attach to the surface and when subjected to an electrical charge can induce assymetrical constrictions resulting in up to a hundred-fold free volume reduction. Chromophores containing copper promote localized constrictions in gels under illumination (Carpita and Gibeaut, 1990).

The anionic pectic gels of cell walls are exposed to charged environments, to cation flux from plasma membranes and eventually to hydric stress, where fluid-body tension causes gel deformation and cell wall tensioning. To estimate $\mathrm{P}_{\mathrm{a}}$ reduction as function of gel volume, we used a much simplified model where fluid volume tension is equivalent to the tension in a fluid-body in a capillary tube submitted to gravitational field: if gel volume, and therefore pores, changes 75 times, its radius $\mathrm{P}_{\mathrm{a}}$ would change 5 times.

Simulations on figures 2 and 3 suggest that cell wall dynamics during growth reduces $\mathrm{P}_{\mathrm{a}}$ effect, whose intensity depends on initial water deficit (see figures 1 and 2). The constitution and physiology of the cell wall explain its behaviour with respect to water available to the plant. This behaviour also depends on its initial hydric state and water availability from that moment. Subsequent simulations consider a plant suffering water deficit, initially negative $\mathrm{P}_{\mathrm{a}}$, and limitless water supply. In this situation, wall hydration corresponds to an initial phase of growth before water begins migrating to the protoplasm. This transitory $\mathrm{P}_{\mathrm{a}}$ characteristic may also be revealed when the elasticity module of the wall is altered, increasing pore size, and tensioning the water column and polymeric wall chains.

High salt concentration, $\mathrm{pH}$ reduction in the walls, high transpiration rates, and small matric potential of the soil are conditions causing wall tensioning. If the concentration is caused by water column tensioning, the $\mathrm{P}_{\mathrm{a}}$ value is reduced. Otherwise the $\mathrm{P}_{\mathrm{a}}$ tends towards positive values. If $\mathrm{P}_{\mathrm{a}}<0$ and the cell is prepared, water flux through the plasma membrane will be determined by a potential gradient through the wall, possibly reduced by liberation of ions through the plasma membrane. When cell wall distention reaches its limit, the elasticity module and turgor diminish, while the $\Psi_{\mathrm{sS}}$ mechanisms permit growth to continue while water supply lasts.

The hydration of leaf parenchyma is strongly influenced by stomatic conductivity and presents interesting transport and water storage characteristics that are more evident in young cells with a good extensibility/elasticity module ratio. Because parenchyma cells are close to the transpiring surface of the leaf, they are also subject to the water content variations which influence $\mathrm{P}_{\mathrm{a}}$. This is evident in the case of tomato fields under controlled irrigation, where leaves were sprayed with water during the experiments of Stirzaker et al. (1997), causing a $0.5 \mathrm{MPa}$ increase of leaf potential in daytime in comparison to a control group subjected to the same irrigation procedure but without spraying.

In a somewhat similar experiment, Shackel et al. (1987) reduced the transpiration rate in grapevine leaves covered by plastic sacks. They measured the turgor of epidermal cells and leaf growth rate. With declining transpiration rate, turgor and leaf growth increased quickly, after which growth resumed initial rate while turgor remained constant. It is possible that in these two examples the apoplasmic hydrostatic pressure reached values close to zero when transpiration was interrupted, eliminating the $\mathrm{P}_{\mathrm{a}}$ term from the growth equations (Eq. 4 and 8). In agreement with this formulation, suction favored growth $(2 \delta / \mathrm{r}-1$ and $\mathrm{Pa}<0)$, which was interrupted when $\Delta \Pi+\left(\frac{2 \delta}{r}-1\right) P_{a}<\frac{2 \delta}{r} Y$. Besides, the transition between hydration states reduced leaf potential in the stressed plants while increasing the turgor accompanying stress rise and fall, suggesting the importance of transitions in the potentials dynamics. 
For Blum and Sullivan (1997), the relationship between stress and the potentials dynamics is not direct. They studied the relationship between plant size and hydric stress only as related to the first $40 \mathrm{~cm}$ of the root system, using four isogenic lines of wheat (Triticum aestivum cv. Bersee), a high, two medium, and a midget, cultivated hydroponically. They measured total potential, osmotic potential, and resistance to diffusion in the leaves, together with size (by height and dry matter), productivity in grain number, and root length. On average, leaf potential dropped -0.097 MPa in control plants and -1.93 MPa in stressed ones that had increased both stomatal resistance and turgor simultaneously. Leaf osmotic potential also diminished. Based on these data, they argued that the stomatal opening is regulated by factors other than the hydric state of the plant, probably by a stress signal from the root zone, and that turgor increase resulted from stomata closing.

It is also possible that osmotic adjustment has an important role in growth by influencing $\mathrm{P}_{\mathrm{a}}$ and $\mathrm{P}_{\mathrm{S}}$ dynamics. Solutions obtained from young pea stem apoplasm by Cosgrove and Cleland (1983) present high solute concentrations, corresponding to a $0.29 \mathrm{MPa}$ osmotic pressure in apical tissues and $0.18 \mathrm{MPa}$ in basal tissues. In six forage grass species, foliar osmotic adjustment permitted turgor maintainance under water stress conditions, together with an elastic module reduction, mainly in $\mathrm{C}_{3}$ types (Barker et al., 1993).

During the osmotic adjustment process, many substances are involved in a possibly species-related pattern. Santarius (1994) quantified the role of soluble sugars (sucrose + glucose + fructose), free amino acids, malate, citrate, and chlorate in osmotic potential formation in meristematic stem tissue from six species of Bryidae. He obtained 15-20\% participation for free amino acids, $10-20 \%$ for carboxylic acids, and a reduced percentage for inorganic anions. Around barley leaf stomatas, Fricke et al. (1995) obtained differences in spatial distribution for $\mathrm{K}^{+}, \mathrm{Ca}^{+2}, \mathrm{Cl}^{-}, \mathrm{NO}^{-3}$, and malate. For lichen shafts, Beckett (1994) obtained a linear tendency between an apoplasmic water fraction and potassium amount in the dry matter $\left(\mu \mathrm{mol} . \mathrm{g}^{-1}\right)$.

Lockhart (1965) best simulated the observed experimental data using two independent approaches: i) $\Delta \Pi$ constant; ii) ion concentration diminishes with growth (in both cases $\phi$ was a linear function decreasing with time). Here we also plotted growth curves under these conditions to evaluate the effect of $\mathrm{P}_{\mathrm{a}}$, where we can see that it is less than $1 \%$ (figures 3 and 4) and so difficult to detect experimentally. The case where $\Delta \Pi$ and $\phi$ are constant (figure 2), although unlikely, is interesting because it exemplifies the $\mathrm{P}_{\mathrm{a}}$ effect.
In the turgor relationship (see table I), the negative $\mathrm{P}_{\mathrm{a}}$ values increase the effect of osmotic potential in the turgor dynamics, causing water suctioning from the interior of the cell wall and, therefore, facilitating protoplasm hydration. With the hydration of protoplasm and consequent increase of its potential, suction is reduced and $\mathrm{P}_{\mathrm{a}}$ tends to zero. In tissues subjected to stress impact or a compression work regime (Canny, 1995b), $\mathrm{P}_{\mathrm{a}}>0$ and the water absorption caused by osmotic potential is restricted by the pressure that the apoplastic compartment exerts on the protoplasm, thus reducing the $\Psi_{\mathrm{SS}}$ effect on the $\mathrm{P}_{\mathrm{S}}$ value.

In the expression for total protoplasmic potential (see table I), the $\Delta \Psi_{\mathrm{SS}}$ is approximately 1.8 times less than that of $\mathrm{P}_{\mathrm{a}}$ while the suction term tends to increase the total potential. It should be noted that positive values for $\mathrm{P}_{\mathrm{a}}$ reduce the total potential, a possible consequence of wall water-storage capacity in detriment to solute dilutions in the protoplasm.

The expression for plastic growth (Eq. 8) is extensively discussed in Calbo and Pessoa (1994) and its equivalent, without the wall potential, is presented in Lockhart (1964).

\section{CONCLUSIONS}

Suction increases the growth rate, before hydrostatic potential of the wall reaches zero.

The study presented here raises some additional questions concerning the role of apoplasm hydrostatic potential in cell growth and is a continuation of Calbo and Pessoa (1994). Their work suggested that suction is also a component of the tensioning force responsible for cell wall lengthening. With the equations here derived, we obtained relationships between apoplasm hydrostatic potential, total and osmotic potentials of the protoplasm, and elastic and viscous lengthening, thus allowing an evaluation of the $\mathrm{P}_{\mathrm{a}}$ effect in the Lockhart model, which considers $\mathrm{P}_{\mathrm{S}}$ as solely responsible for wall tensioning. For obtaining the growth curves, it is assumed that $\mathrm{P}_{\mathrm{a}}$ presents a logistically described behavior, affecting mainly the initial lengthening.

Despite the restrictions imposed for the deduction of the equations, the results presented here contribute to our understanding of the role of $\mathrm{P}_{\mathrm{a}}$ in cell growth.

Aknowledgements: This work was supported by Embrapa (SEP 12.1999.100) and Fapesp (00/08552-2)

\section{REFERENCES}

Baker DJ, Sullivan C Y, Moser, LE (1993) Water deficit effects on osmotic potential, cell wall elasticity, and proline in five forage grasses. Agron. J. 85:270-275. 
Beckett RP (1995) Some aspects of the water relations of lichens from habitats of contrasting water status studies using thermocouple psychrometry. Ann. Bot. 76:211-217.

Blum A, Sullivan CY (1997) The effect of plant size on wheat response to agents of drought stress. I. Root drying. Austr. J. Plant Physiol 24:35-41.

Calbo AG, Pessoa JDC (1994) A plant growth re-analysis. An extension of Lockhart's equation to multicellular plants. Rev. Bras. Fisiol. Veg. 6:83-90.

Canny MJ (1995a). Apoplastic water and solute movement: new rules for an old space. Annu. Rev. Plant Physiol. 46:215-236.

Canny MJ (1995b) A new theory for the ascent of sap-cohesion supported by tissue pressure. Ann. Bot. 75:343-357.

Chimenti CA, Hall AJ (1994) Responses to water stress of apoplastic water fraction and bulk modulus of elasticity in sunflower (Helianthus annuus L.) genotypes of contrasting capacity for osmotic adjustment. Plant Soil 166:101-107.

Cleland R (1971) Cell wall expansion. Annu. Rev. Plant Physiol. 22:197-222.

Cosgrove DJ (1993) How do plant cell walls extend? Plant Physiol. 102:1-6.

Cosgrove DJ, Clealand, RE (1983) Solutes in the free space of growing stem tissues. Plant Physiol. 72:326-332.

Fricke W, Hinde PS, Leigh RA, Tomos AD (1995) Vacuolar solutes in the upper epidermis of barley leaves. Planta 196:40-49.

Hsiao TC (1973) Plant responses to water stress. Annu. Rev. Plant Physiol. 24:519-570.

Kutschera U (2000) Cell expansion in plant development. Rev. Bras. Fisiol. Veg. 12:65-95
Lockhart JA (1965) An analysis of irreversible plant cell elongation. J. Theor. Biol. 8:264-275.

McCann MC, Roberts K (1994) Changes in cell wall architecture during cell elongation. J. Exp. Bot. 45:1683-1691.

Nakajima N, Morikawa H, Igarashi S, Senda M (1981) Differential effect of calcium and magnesium on mechanical properties of pea stem cell walls. Plant Cell Physiol. 22:1305-1315.

Neumann PM, Azaizeh H, Leon D (1994) Hardening of root cell walls: a growth inhibitory response to salinity stress. Plant Cell Environ. 17:303-309.

Passioura JB (1994) The physical chemistry of the primary cell wall: implications for the control of expansion rate. J. Exp. Bot. 45:1675-1682.

Salisbury F, Ross CW (1992) Plant Physiology, 4a ed., Wadsworth publishing, Belmont.

Santarius K (1994)Apoplasmic water fractions and osmotic potentials at full turgidity of some Bryidae. Planta 193:32-37.

Shackel KA, Matthews MA, Morrison JC (1987) Dynamic relation between expansion and cellular turgor in growing grape (Vitis vinifera L.) leaves. Plant Physiol. 84:116-1171.

Shackel KA, Greve C, Labavitch JM, Ahmadi H (1991) Cell turgor changes associated with ripening in tomato pericarp tissue. Plant Physiol. 97:814-816.

Stirzaker RJ, Hayman PT, Sutton BG (1997) Misting of tomato plants improves leaf water status but not leaf growth. Aust. J. Plant Physiol. 24:9-16.

Taiz L (1984). Plant cell expansion: regulation of cell wall mechanical properties. Ann. Rev. Plant Physiol. 35:585-657.

Tomos AD (1988) Celullar water relations of plants. Water Sci. Rev. 3:186-277. 